\title{
$X$-ray spectra in SEM and staining with chrome azurol $S$ show Al deposits in leaf tissues of Al-accumulating and non-accumulating plants from the cerrado
}

\author{
Anna C. G. Bressan • Alessandra I. Coan • \\ Gustavo Habermann
}

Received: 23 June 2015 / Accepted: 18 February 2016/Published online: 2 March 2016

(C) Springer International Publishing Switzerland 2016

\begin{abstract}
Aims Aluminum (Al) accumulating plants are distributed throughout the world. In the Cerrado, Alaccumulating and non-accumulating species coexist. Therefore, we anatomically/histochemically explore the sites of $\mathrm{Al}$ deposits in $\mathrm{Al}$-accumulating species, and we also ask whether $\mathrm{Al}$ can be observed in nonaccumulating species.

Methods The anatomical patterns of Al storage in leaf tissues of Al-accumulating [Miconia albicans, M. rubiginosa (Melastomataceae), Qualea grandiflora, and $Q$. parviflora (Vochysiaceae)] and nonaccumulating species [(Styrax ferrugineus and $S$. camporum (Styracaceae)] were described using different Al indicator dyes: hematoxylin and chrome azurol $\mathrm{S}$ (CAS). In addition, Al-specific x-ray spectra from different regions of leaf tissues were measured and analyzed by scanning electron microscopy (SEM).

Results When compared to hematoxylin, it was confirmed by $x$-ray spectra in SEM that CAS was a more
\end{abstract}

Responsible Editor: Jian Feng Ma.

A. C. G. Bressan

Programa de Pós-Graduação em Ciências Biológicas (Biologia Vegetal), Instituto de Biociências, Departamento de Botânica, Univ Estadual Paulista, Unesp, Av. 24-A, 1515, Rio Claro, SP 13506-900, Brazil

A. I. Coan · G. Habermann $(\bowtie)$

Instituto de Biociências, Departamento de Botânica, Univ Estadual Paulista, Unesp, Av. 24-A, 1515, Rio Claro, SP 13506-900, Brazil

e-mail: ghaber@rc.unesp.br contrasting indicator of Al presence. Silica granules associated to Al were observed on cell walls of nonlignified leaf tissues of Al-accumulating species. However, granules were also found in leaf midribs of S. camporum.

Conclusions The anatomical description of $\mathrm{Al}$ accumulation in leaves and the consistent pattern of $\mathrm{Al}$ association with cell walls strongly suggest that $\mathrm{Al}$ has structural rather than physiological roles in leaves of Cerrado woody plants, and that $\mathrm{Al}$ is perhaps isolated from metabolism.

Keywords $\mathrm{Al}^{3+} \cdot$ Brazilian savanna $\cdot$ Histochemical studies $\cdot$ Melastomataceae $\cdot$ Styracaceae $\cdot$ Vochysiaceae

\section{Introduction}

Acidic soils ( $\mathrm{pH}<5.0$ ) occupy approximately $30 \%$ of the world's ice-free land areas, where $67 \%$ support woodlands and forests, and $18 \%$ savannas (vonUexküll and Mutert 1995). Acidic soils usually present low base (K, Ca and $\mathrm{Mg}$ ) saturation (BS) and, consequently, high values of potential acidity $\left(\mathrm{H}^{+}+\right.$ $\mathrm{Al}^{3+}$ ) and exchangeable aluminum (Al) (Robson 1989). Poor soils and edaphic $\mathrm{Al}$ are known to limit the growth of crop plants (Yang et al. 2013), as Al causes ruptures in roots, binding itself to cell walls of rhizodermis and increasing its rigidity while reducing the ability of outer cells to elongate (Kopittke et al. 2008). Some plants form complexes of malate and citrate with $\mathrm{Al}$ in the root tip, and specific transporters are 
responsible for excluding these organic acid complexes, explaining the resistance of some genotypes, which are called Al excluders (Ryan et al. 2011).

However, Al-accumulating plants are able to grow on acidic and Al-rich soils. Examples come from plants from the Rubiaceae family found in swamp forests in Brazil (Britez et al. 2002), Melastomataceae growing in highly disturbed landscapes in Mexico (GonzálezSantana et al. 2012), 127 Melastomataceae species from different parts of the world (Jansen et al. 2002), 11 from Rubiaceae species distributed worldwide (Jansen et al. 2003), and even from tea plants - Theaceae (Carr et al. 2003; Tolrà et al. 2011).

In the Cerrado, which comprises grasslands, savannas and forests physiognomies, vegetation grows on more acidic $(\mathrm{pH}<4.0)$ soils with $\mathrm{Al}$ saturation $>70 \%$ (Haridasan 2008; Habermann and Bressan 2011). In the Cerrado, A1accumulating plants were first described in 1982, and because of edaphic conditions, A1accumulating and non-accumulating species were identified; while the former accumulates between 1000 up to 15,000 (or more) mg $\mathrm{Al}$ per $\mathrm{kg}$ dry leaves, the latter presents between 600 and $1000 \mathrm{mg} / \mathrm{kg}$ (Haridasan 1982). According to this author, most Al-accumulating plants in the Cerrado are shrubs and trees from Melastomataceae, Rubiaceae and Vochysiaceae.

Using $\mathrm{Al}$ indicators (dyes) in hystochemical tests, $\mathrm{Al}$ deposition was observed on cell walls of the phloem of the midrib and secondary veins of Al-accumulating plants from the Cerrado (Haridasan et al. 1986). These authors also showed that xylem fibers and xylem vessels do not get stained, while cell walls of the collenchyma, spongy parenchyma and guard cells do. This pattern was reported for other Al-accumulating plants that are not from the Cerrado (Britez et al. 2002; Carr et al. 2003; Tolrà et al. 2011; González-Santana et al. 2012), although in Melastoma malabathricum, Tibouchina urvilleana (Melastomataceae) and Symplocos chinensis (Symplocaceae), all Al-accumulators, Al was evidenced only in trichomes and epidermis and none in the mesophyll (Maejima et al. 2014).

Inferring physiological roles for the $\mathrm{Al}$ in the metabolism of these plants, however, is quite challenging. For example, Vochysia thyrsoidea (Vochysiaceae) and Miconia albicans (Melastomataceae) from the Cerrado exhibit leaf chlorosis and poor growth when cultivated in alkaline calcareous soils (Haridasan 2008). Recently,
$\mathrm{Al}$ has been suggested to have some unknown role in chloroplasts, since it was observed in these organelles (Andrade et al. 2011).

Another dissension among researchers derives from the use of different dyes as Al-indicators. Most studies use hematoxylin (González-Santana et al. 2012; Andrade et al. 2011) and aluminon (Chenery 1948; Haridasan et al. 1986; Jansen et al. 2002), but it has been demonstrated that these dyes also react with $\mathrm{Fe}, \mathrm{Cu}$ and $\mathrm{Zn}$ rather than reacting specifically with $\mathrm{Al}$ deposited in plant tissues. Here, we compared hematoxylin with chrome azurol S (CAS) and demonstrate that the latter is more efficient.

In addition, leaf $\mathrm{Al}$ concentration is not always concomitantly measured when investigating Alaccumulating plants, and micromorphology has not yet been used to study Al-accumulating plants from the Cerrado. Thus, besides confirming anatomical patterns of $\mathrm{Al}$ deposition in leaf tissues from these plants, in this paper we analytically quantified $\mathrm{Al}$ in leaves from some Al-accumulating and non-accumulating species growing in the field. As a novelty, we analyzed the micromorphology (Al-specific x-ray coupled to scanning electron microscope) to identify where Alaccumulating plants store $\mathrm{Al}$ in their leaves, and we hypothesized that $\mathrm{Al}$ cannot be evidenced in nonaccumulating species.

\section{Material and methods}

\section{Plant material}

Leaves of Al-accumulating and non-accumulating plants were collected in the field. Al-accumulating plants were Qualea grandiflora Mart., Q. parviflora Mart. (Vochysiaceae), Miconia albicans (SW) Triana and M. rubiginosa (Bonpl.) DC (Melastomataceae), and the non-accumulating species were Styrax ferrugineus Nees \& Mart. and S. camporum Pohl. (Styracaceae). These were adult trees (5-10 $\mathrm{m}$ tall) and shrubs (3-5 m tall) naturally occurring in cerrado sensu stricto (savanna-type physiognomy) remnants and in a forest-type physiognomy called 'Cerradão' (a more densely treed savanna, whose name is the augmentative of 'Cerrado' in Portuguese).

These species from Vochysiaceae and Melastomataceae have been described as Al-accumulating plants since 1982 (Haridasan 1982). The two Al non-accumulating species 
from the Styracaceae family were chosen not only because they do not appear on the list of Al-accumulating plants (Haridasan 1982), but also because we knew previously (unpublished data) that they accumulate low amounts of $\mathrm{Al}$ in their leaves, which makes them good contrasting plants growing on the same soils as Al-accumulating plants do in the Cerrado.

\section{Study sites}

The field sites were located in the municipalities of Mogi-Guaçu, Itirapina and Corumbataí in São Paulo state, Brazil, in the southern part of the Cerrado vegetation in South America. In Mogi-Guaçu, plants were found in a cerrado sensu stricto remnant and also in a Cerradão area, on 'Campininha' farm at the 'Reserva Biológica de Mogi-Guaçu' (22 $2^{\circ} 15^{\prime} 19^{\prime \prime} \mathrm{S} 47^{\circ} 09^{\prime} 30^{\prime \prime}$ $\mathrm{W} ; 680 \mathrm{~m}$ of altitude; $340 \mathrm{ha}$ ), a Cerrado area that has been preserved in its natural condition since 1950 .

In Itirapina, plants were found in a cerrado sensu stricto fragment $\left(22^{\circ} 13^{\prime} \mathrm{S} 47^{\circ} 53^{\prime} \mathrm{W} ; 610 \mathrm{~m}\right.$ of altitude; 260 ha) on 'São José da Conquista' farm; and in Corumbataí, plants were growing in a Cerradão fragment $\left(22^{\circ} 15^{\prime} \mathrm{S}, 47^{\circ} 00^{\prime} \mathrm{W} ; 860 \mathrm{~m}\right.$ of altitude; $\left.38.7 \mathrm{ha}\right)$.

\section{Experimental strategy}

In each of these three sites, soil samples were collected at $20-30 \mathrm{~cm}$ of depth, where the uptake of nutrients takes place for most native plants (Wigley et al. 2013). Fertility parameters, but most importantly, soil Al saturation $(\mathrm{Al} \%$ ) was measured to support our results of leaf $\mathrm{Al}$ accumulation. We sought $\mathrm{Al}$ presence in leaf tissues using histochemical tests with different dyes. For this, leaves from the Al-accumulating and non-accumulating species were cut and stained with hematoxylin and CAS, and were compared to non-dye treated cuts. In addition, Al-specific x-ray spectra from different regions of leaf tissues were measured and analyzed by scanning electron microscopy (SEM).

\section{Soil fertility and leaf $\mathrm{Al}$ concentration}

Five soil samples were randomly collected in each site and taken to the Soil Science Lab at the University of São Paulo (Esalq, USP, Piracicaba, SP) for routine soil chemical (fertility) analysis ( $\mathrm{pH}$ in $\mathrm{CaCl}_{2}$ ), which was performed according to van Raij et al. (2001), and the procedures are described in English by Dantas and Batalha (2011).

In each of the three sites, at least five plants of each species available in the area were identified and had their leaves (leaf lamina with its petiole) collected. For this, each plant had its canopy subdivided into the four geographical quadrants (N, S, E and W) where mature fully expanded leaves were collected. The leaf samples ( \pm 40 leaves per tree) were, then, taken to the Plant Nutrition Lab at the University of São Paulo (Esalq, USP, Piracicaba, SP) for analysis of $\mathrm{Al}$ concentration. The leaves were oven-dried at $60{ }^{\circ} \mathrm{C}$ to constant dry mass, ground and digested in a solution of sulfuric:nitric:percloric acids (1:10:2, v/v/v). After digestion, $\mathrm{Al}$ concentrations were determined by the atomic absorption spectrophotometer method (Sarruge and Haag 1974) and expressed as mg Al per kg dry leaves.

\section{Anatomical studies}

Some shoots collected from each plant were separated and taken freshly (moistened and put in a plastic bag) to the Plant Anatomy Lab at the São Paulo State University (Unesp) for the anatomical analyses of their leaves.

The leaves were fixed in FAA 50 (37\% formaldehyde, glacial acetic acid, $50 \%$ ethanol; 1:1:18 v:v:v) and preserved in $70 \%$ alcohol (Johansen 1940), according to Andrade et al. (2011). We also stained fresh tissues with both dyes, and the staining patterns were the same as those obtained when the plant material was fixed (FAA 50) and preserved (70\% alcohol). The anatomical study was based on consecutively-sliced cross sections from the same leaf segments $\left(1 \mathrm{~cm}^{2}\right)$ from leaf midribs containing part of the leaf lamina for each species. These sections were cut manually with a razor blade. Non-dye treated cuts were immersed in distilled water for $15 \mathrm{~min}$ before mounting semi-permanent glass slides. Dye-treated cuts were stained for $45 \mathrm{~min}$ (at room temperature) as no staining difference was observed after 20,30, 40 or $60 \mathrm{~min}$ in the staining solutions. These were washed thrice (15 min each) in distilled water and mounted in semi-permanent glass slides. All cuts were, then, observed under light microscope (DMLB, Leica Microsystems, Wetzlar, Germany). The images were captured with a digital camera (DFC-290, Leica Microsystems, Germany) functionally attached to the DMLB. 
Chrome azurol S (CAS), or Mordant blue 29 (3"sulpho-2", 6" - dichloro-3, 3'-dimethy 1-4hydroxyfuchson-5,5'-dicarboxylic acid), $50 \%$ purity (Sigma-Aldrich, St. Louis, MO, USA) solution was prepared dissolving $20 \mathrm{~mL}$ of a $41.3 \mathrm{mM}$ CAS solution $(25 \mathrm{~g} / \mathrm{L})$ into $80 \mathrm{~mL}$ of a $760 \mathrm{mM}$ and $4.82 \mathrm{pH}$ sodium acetate solution (Kukachka and Miller 1980). Therefore, CAS final concentration was $8.3 \mathrm{mM}(5 \mathrm{~g} / \mathrm{L})$ $(\mathrm{pH}=4.76 \pm 0.01)$.

Hematoxylin $(7,11$ b-dihydroindeno[2,1c] chromene-3,4,6a,9,10(6H)-pentol), P.A. (Impex, Diadema, SP, Brazil) solution was prepared dissolving $80 \mathrm{~mL}$ of a $8.3 \mathrm{mM}$ hematoxylin solution $(2.5 \mathrm{~g} / \mathrm{L})$ into $20 \mathrm{~mL}$ of a $4.7 \mathrm{mM}$ and $5.2 \mathrm{pH} \mathrm{KIO}_{3}$ solution (Andrade et al. 2011). Therefore, hematoxylin final concentration was $6.6 \mathrm{mM}(2 \mathrm{~g} / \mathrm{L})(\mathrm{pH}=5.8 \pm 0.05)$.

\section{Micromorphological studies}

For the scanning electron microscopy (SEM), the leaf segments were fixed in a $2.5 \%(\mathrm{v} / \mathrm{v})$ Karnovsky solution (with $0.1 \mathrm{M}$ phosphate buffer, at $\mathrm{pH} 7.3$; overnight at $4{ }^{\circ} \mathrm{C}$ ) and dehydrated in an increasing acetone series of 50, 70, 90, 95, and $2 \times 100 \%$, kept for $15 \mathrm{~min}$ in each step, before mounting these leaf segments on stubs.

Stubs are also made of $\mathrm{Al}$, which could interfere with the Al spectra emited from the plant material. Therefore, before mounting the plant material directly on stubs, we compared x-ray spectra obtained from stubs (with no plant material) when covered and not covered with two layers of a carbon tape (Double sided carbon tape, $8 \mathrm{~mm}$ in width; Electrom Microscopy Science, EMS, USA). We noted that the Al from stubs has no influence on spectra obtained from the plant material.

The images were obtained from a scanning electron microscope (TM 3000, Hitachi, Japan) operated at $15 \mathrm{kV}$, and the $\mathrm{Al}(1.48-1.55 \mathrm{keV})$, as well as silicon ( $\mathrm{Si} ; 1.73-1.83 \mathrm{keV})$ and calcium $(\mathrm{Ca} ; 3.69-4.02 \mathrm{keV})$ detection was performed using an x-ray energy dispersive detector (Swift ED 3000, Hitachi, Japan). The counts were done over a 60 -s period, spectra were recorded and qualitative data were expressed as counts to the second ratio (relative intensity).

The same plant material was compared under light microscopy and SEM to check the correspondence between images and their respective spectrum of emitted Al.

\section{Results}

Soils from the three experimental sites were acidic $(\mathrm{pH}<4.0)$ with low concentrations of $\mathrm{P}, \mathrm{K}, \mathrm{Ca}$ and $\mathrm{Mg}$, resulting in low BS. These soils also showed relatively low cation exchange capacity (CEC), while $\mathrm{Al} \%$ was between 77 and $86 \%$ (Table 1).

Nutritional analysis of leaves showed that the most Al-accumulating species were those from Vochysiaceae and Melastomataceae (Q. parviflora $>M$. al bicans $>M$. rubiginosa $>Q$. grandiflora), whereas $S$. ferrugineus showed the lowest $\mathrm{Al}$ concentration in its leaves (Table 2). Surprisingly, S. camporum, which is not considered an Al-accumulating species, showed approximately $1000 \mathrm{mg} \mathrm{Al}$ per $\mathrm{kg}$ dry leaves.

Hematoxylin and CAS reacted positively with all Al-accumulating species (Figs. 1, 2, 3 and 4), but negatively with those considered nonaccumulating ones (Figs. 5 and 6). For M. rubiginosa, hematoxylin stained in red (Fig. 1c, d), and CAS, in purple (Fig. 1e, f), exhibiting a clear contrast with non-dye treated cuts (Fig. 1a, b). The same colors were observed for $M$. albicans when stained with hematoxylin (Fig. 2c, d) and CAS (Fig. 2e, f) when compared with its non-dye treated cuts (Fig 2a, b). However, CAS contrasted the positive and negative reactions in the midrib and leaf lamina more intensely when compared to hematoxylin (Figs. 1 and 2). When hematoxylin was used, intercellular spaces and cell walls of both the parenchyma and collenchyma of the midrib (Fig. 2d) did not react as clear as when CAS was used (Fig. 2f).

We observed positive reactions on cell walls of epidermal surfaces, phloem, parenchyma, and collenchyma of the midrib (Table 3). Positive reactions were evident in vacuoles of the parenchyma of the midrib (Fig. 1f, $3 \mathrm{~d}$ and $4 \mathrm{~b}$ ), and these reactions also showed $\mathrm{Al}$ as content of phloem cells (Fig. 1d and f). Cell walls of both the xylem and sclerified cells reacted negatively (Table 3 ) with hematoxylin (Fig. 1d and 2d) and CAS (Fig. 1f, 2f, and $3 \mathrm{~d})$.

Chrome azurol $\mathrm{S}$ also stained phloem cell walls in the vascular bundle of M. rubiginosa (Fig. 3b). The palisade parenchyma stained in red when treated with CAS, contrasting with its purple positive reaction noticed for the spongy parenchyma (Fig. 3b). We observed no reactions with the internal contents of chloroplasts. 


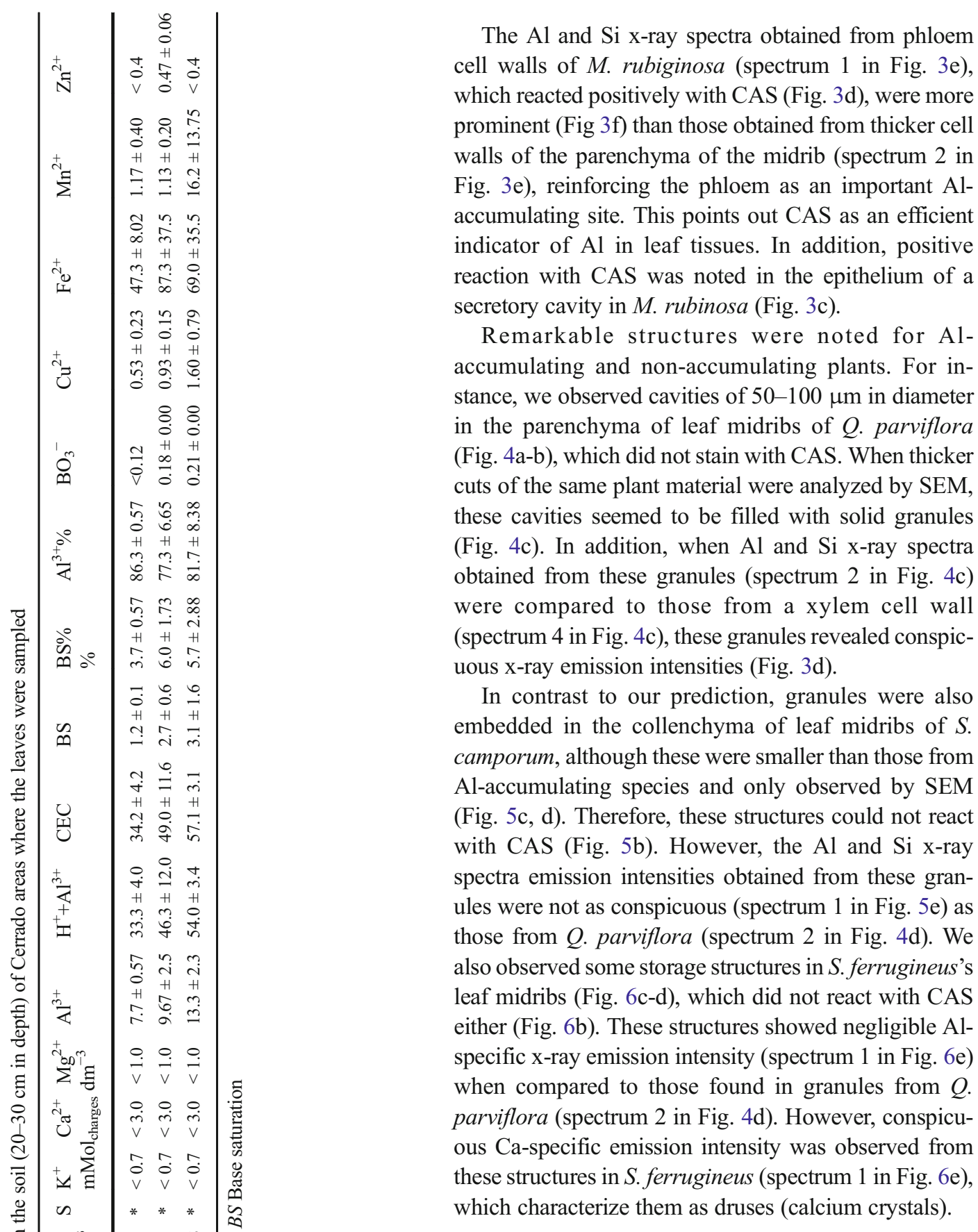

\section{Discussion}

Our results show that CAS gives sharper contrasting results compared to hematoxylin when reacting with $\mathrm{Al}$ in plant tissues. Aluminon has long been used to identify Al-accumulating plants by the intensity of colors (Chenery 1948; Jansen et al. 2002) produced by 
Table 2 Aluminum concentrations in leaves of Al-accumulating and non-accumulating species growing in the studied Cerrado areas

\begin{tabular}{llll}
\hline Family & Species & Site & Al concentration mg kg $^{-1}$ \\
\hline Vochysiaceae & Q. grandiflora & Itirapina & $3833.4 \pm 691.1$ \\
& & Mogi-Guaçu & $4035.4 \pm 2439.7$ \\
& & Corumbataí & $5442.1 \pm 804.3$ \\
Melastomataceae & M. parviflora & Mogi-Guaçu & $9876.3 \pm 1004.9$ \\
& M. albicans & Itirapina & $3116.7 \pm 1463.3$ \\
S. rubiginosa & Mogi-Guaçu & $8628.8 \pm 1185.8$ \\
& & Itirapina & $2284.2 \pm 242.6$ \\
& S. ferrugineus & Mogi-Guaçu & $5457.8 \pm 499.5$ \\
& & Itirapina & $300.9 \pm 48.6$ \\
& S. camporum & Mogi-Guaçu & $218.2 \pm 16.5$ \\
\end{tabular}

the reaction between this dye and Al-rich plant material. For $Q$. grandiflora, hematoxylin has already been used to identify $\mathrm{Al}$ in the mesophyll (Andrade et al. 2011). In fact, different dyes (ferron, morin, pyrocatechol violet, aluminon, CAS and hematoxylin) can detect monomeric $\mathrm{Al}\left(\mathrm{Al}^{3+}\right)$ (Wehr et al. 2010). Pyrocatechol violet,
Fig. 1 General aspects (a, c and e) and respective details (b, $\mathbf{d}$ and f) from serial cross-sections of leaf midribs of Miconia rubiginosa. $\mathbf{a}$ and $\mathbf{b}$ : non-stained; $\mathbf{c}$ and $\mathbf{d}$ : stained with

hematoxylin; $\mathbf{e}$ and $\mathbf{f}$ : stained with chrome azurol $\mathrm{S}$.

co = collenchyma; $\mathrm{ph}=$ phloem; $\mathrm{xy}=$ xylem; $*=$ sclerified cells.

Scale bars: $\mathbf{a}, \mathbf{c}$ and $\mathbf{e}=200 \mu \mathrm{m} ; \mathbf{b}$, $\mathbf{d}$ and $\mathbf{f}=100 \mu \mathrm{m}$
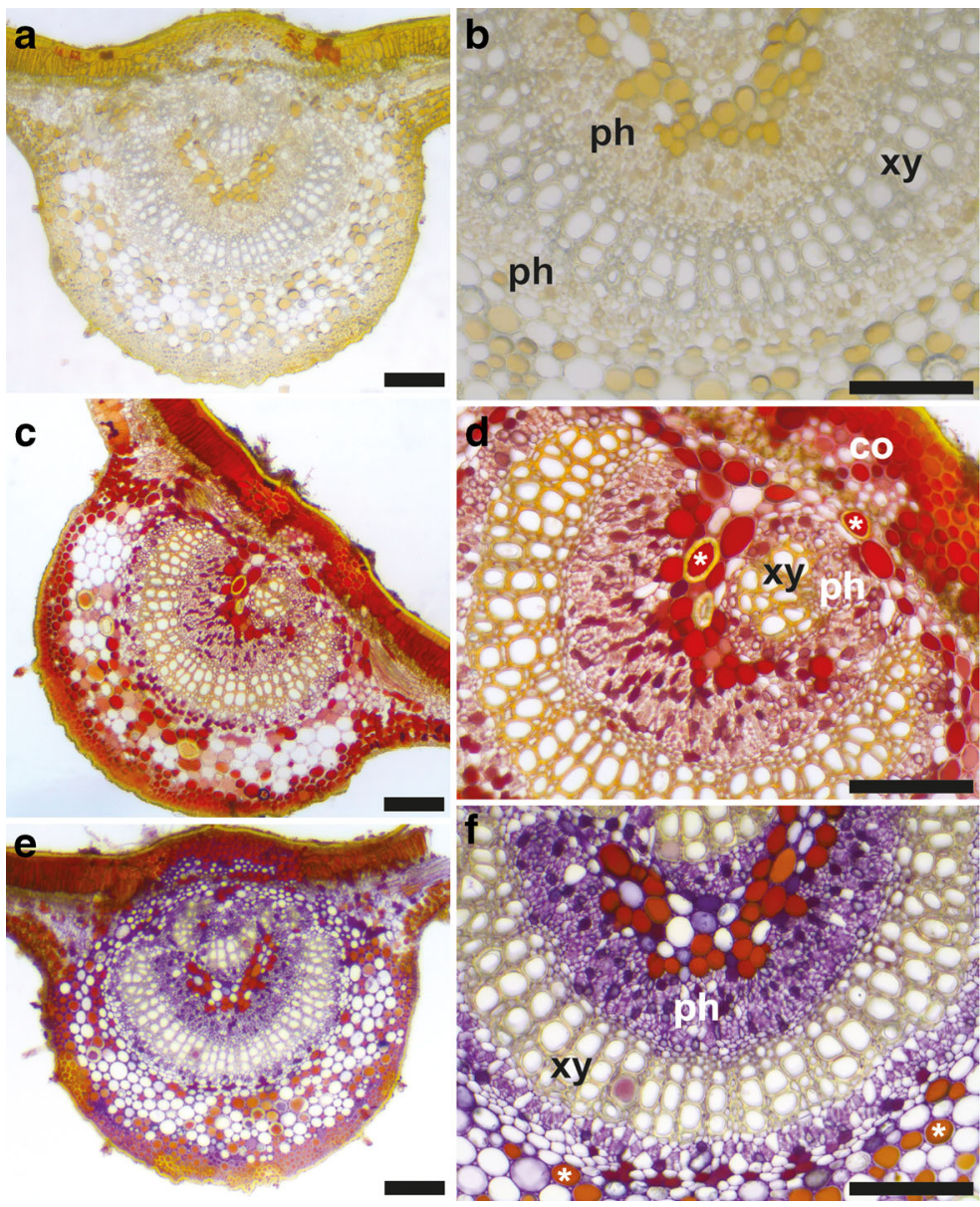
Fig. 2 General aspects (a, c and e) and respective cortex details (b, d and f) from serial cross-sections of leaf midribs of Miconia albicans. $\mathbf{a}$ and $\mathbf{b}$ : non-stained; $\mathbf{c}$ and $\mathbf{d}$ : stained with hematoxylin; e and $\mathbf{f}$ : stained with chrome azurol S. co = collenchyma; $\mathrm{ph}=$ phloem; $\mathrm{xy}=$ xylem; $*=$ sclerified cells. Scale bars: a, c and $\mathbf{e}=200 \mu \mathrm{m} ; \mathbf{b}, \mathbf{d}$ and $\mathbf{f}=100 \mu \mathrm{m}$
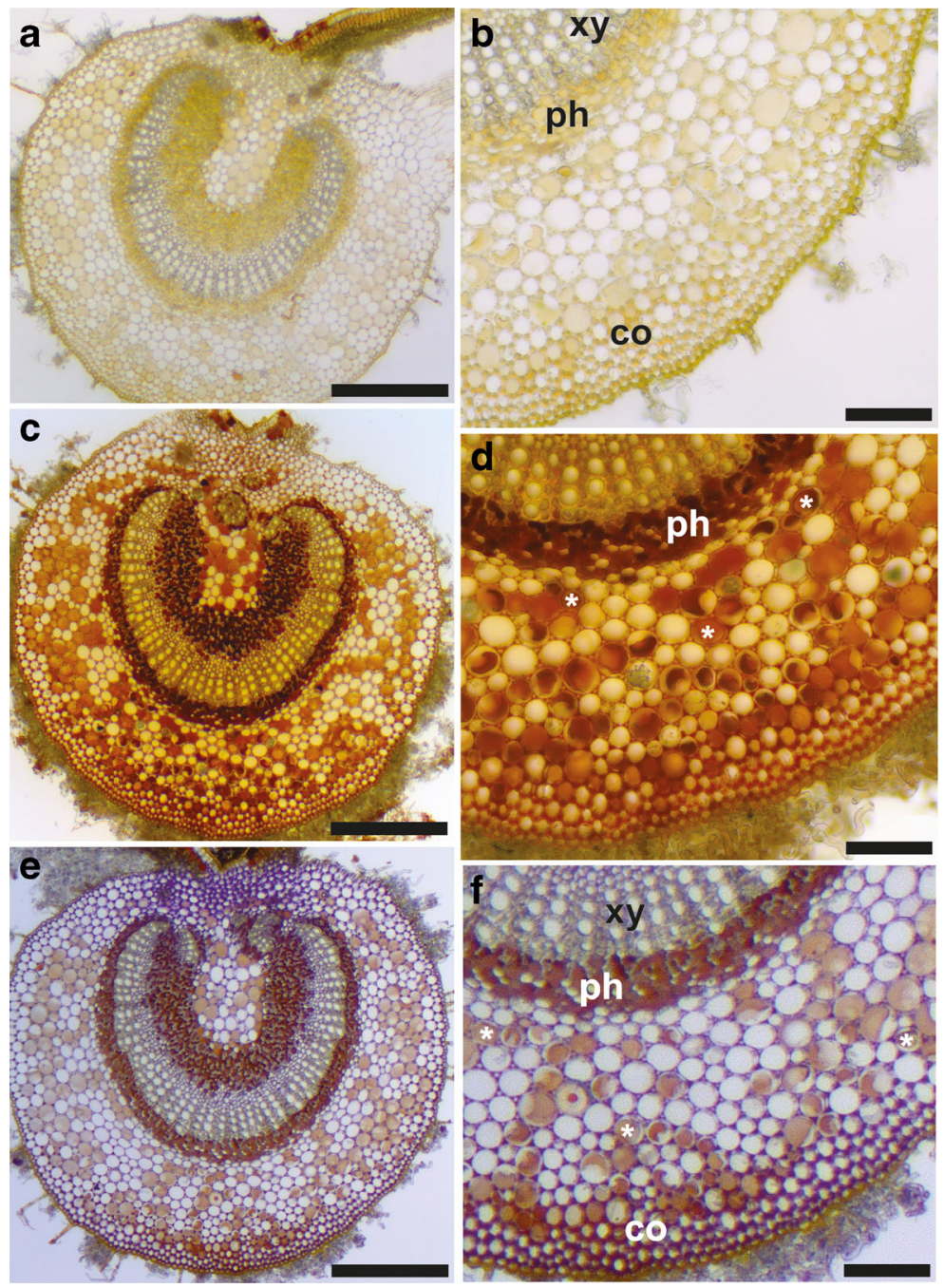

however, also react with $\mathrm{Fe}, \mathrm{Cu}$ and $\mathrm{Zn}$ (GonzálezSantana et al. 2012), and hematoxylin is also known to react with $\mathrm{Fe}$ salts. Chrome azurol $\mathrm{S}$ can also react with $\mathrm{Fe}, \mathrm{Cu}$ and $\mathrm{Zn}$. However, in acidic solutions $(\mathrm{pH}<5.0)$ these reactions are minimized. The interference of $\mathrm{Fe}$ in Al-CAS complexes is much larger at $\mathrm{pH} 5.1$ than at pH 4.6 (Pakalns 1965). For this same reason, a Naacetate buffer solution is recommended when using CAS as an Al indicator (Wehr et al. 2010), and the CAS solution we used showed $4.76 \pm 0.01 \mathrm{pH}$.

On plant cell walls, small Al-hydroxy species, which are present on pectins and other cell wall compounds (Wehr et al. 2010), can be indicatively stained by CAS (Kennedy and Powell 1986). The color given by the reaction between an $\mathrm{Al}$ indicator and the tissue is also important and dependent on the $\mathrm{pH}$ of the solution, but the highest absorbance of Al-CAS complexes is observed within 470-550 nm, regardless of the $\mathrm{pH}$ in the $3.0-5.0 \mathrm{pH}$ range, where the indicative color of $\mathrm{Al}$ presence is purple (Wehr et al. 2010), the same color we observed in Al-accumulating plants. Chrome azurol $\mathrm{S}$ has been used even to estimate $\mathrm{Al}$ concentration in plant material (Jansen et al. 2000). The use of CAS is considerably more reproducible and selective than aluminon (Pakalns 1965). Therefore, we suggest CAS and not hematoxylin to anatomically observe $\mathrm{Al}$ accumulation in plant tissues.

Our results also show that $\mathrm{Al}$ is anatomically associated with tissues composed mainly by primary cell walls (phloem, collenchyma, epidermis and parenchyma) and hematoxylin, but most importantly, CAS does not stain tissues containing lignin, 
Fig. 3 Anatomical analyses from cross-sections of leaf lamina (a, $\mathbf{b}$ and c) and abaxial midrib (d) of M. rubiginosa performed under light microcopy (a, b, c and d) and SEM (e). a: nonstained; $\mathbf{b}, \mathbf{c}$ and $\mathbf{d}$ : stained with chrome azurol S. vs = vascular sheath; pp. $=$ palisade parenchyma; sp. = spongy parenchyma; $*=$ sclerified cells; e: Al- and Si-specific energydispersive $\mathrm{x}$-ray spectra from the phloem and a thick cell wall in the cortical parenchyma. Scale bars: a, $\mathbf{b}$ and $\mathbf{c}=50 \mu \mathrm{m} ; \mathbf{d}=100 \mu \mathrm{m}$; $\mathbf{e}=30 \mu \mathrm{m}$
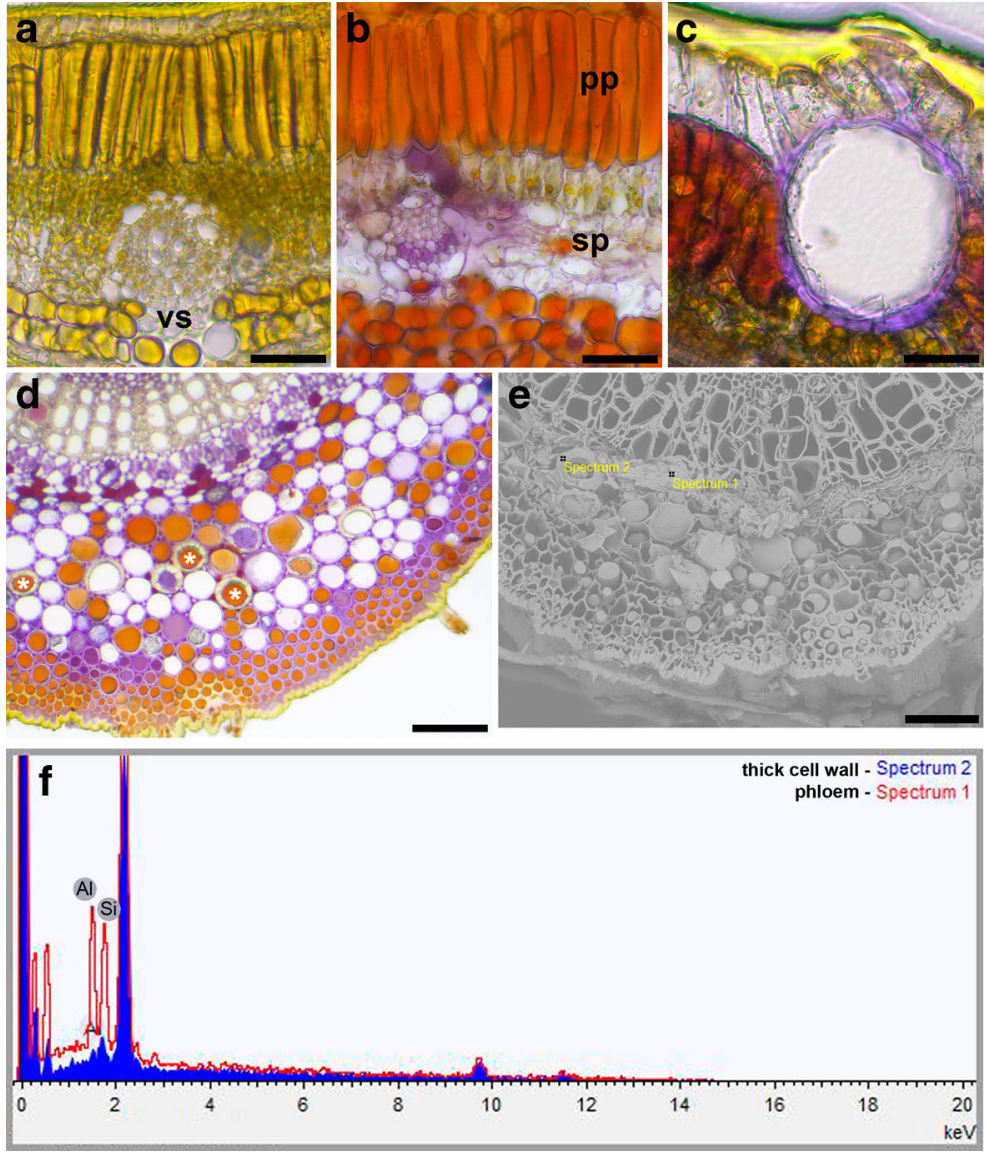

such as xylem and sclerified cells. Moreover, Al is anatomically associated with the middle lamella, as CAS $x$ Al positive reaction was evidenced in the parenchyma of the midrib of M. albicans (Fig. 2f). This indicates that the lack of pectin may be a possible impairment of Al biding to the cell wall, corroborating Wehr et al. (2010). The cell wall of both epidermal surfaces seems to be the primary site for $\mathrm{Al}$ accumulation in leaves. This pattern was already reported for other Al-accumulating plants not from the Cerrado, such as Faramea marginata [Rubiaceae (Britez et al. 2002)], Camellia sinensis [Theaceae (Carr et al. 2003; Tolrà et al. 2011)] and Conostegia xalapensis [Melastomataceae (González-Santana et al. 2012)]. Pyrocatechol violet stains the cell wall of the spongy parenchyma, but not the sclerenchyma or the xylem of F. marginata (Britez et al. 2002). In Melastoma malabathricum, Tibouchina urvilleana (Melastomataceae) and Symplocos chinensis (Symplocaceae) grown under $500 \mu \mathrm{M}$ Al, pyrocatechol violet stained trichomes and leaf epidermis (Maejima et al. 2014) whose cells do not contain lignin.

Although Haridasan et al. (1986) already reported the above-mentioned patterns of Al-tissue reaction with aluminon in Al-accumulating plants from the Cerrado, evidence for physiological function(s) of $\mathrm{Al}$ in the metabolism of these plants is sought. As these authors showed the positive reaction of $\mathrm{Al}$ in the phloem of leaf midribs of these plants, and later found significant amounts of $\mathrm{Al}$ in seeds of $\mathrm{Al}-$ accumulating plants (Haridasan 2008), a phloem transport mechanism for $\mathrm{Al}$ has been proposed. Using cryo-fixation of plant material, which avoids retranslocation of elements during sample preparation for observation with low energy $\mathrm{x}$-ray fluorescence spectro-microscopy, Tolrà et al. (2011) were able to confirm Al storage in the leaf phloem of C. sinensis. These findings strongly suggest that Al-citrate, Almalate or Al-oxalate (Brunner and Sperisen 2013) flowing through the xylem sap (Watanabe and 
Fig. 4 Anatomical analyses from cross-sections of leaf midribs (a, b and c) of $Q$. parviflora performed under light microscopy (a and b) and SEM (c). a: non-stained; b: stained with chrome azurol S; ca = cavities; $\mathbf{d}$ : Al- and Si-specific energydispersive $\mathrm{x}$-ray spectra from the xylem and a granule in the cortical parenchyma. Scale bars: a and $\mathbf{b}=200 \mu \mathrm{m} ; \mathbf{c}=50 \mu \mathrm{m}$
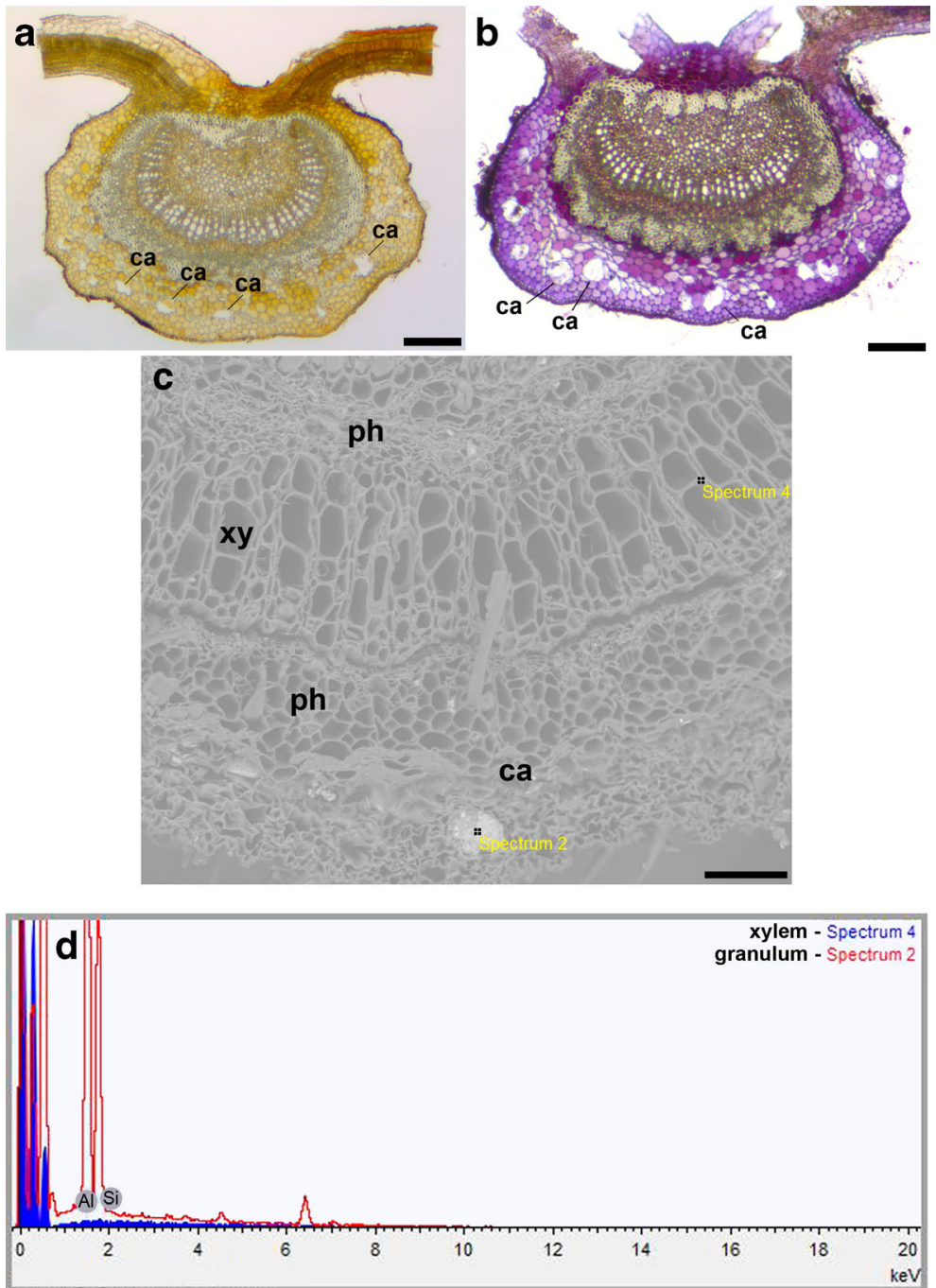

Osaki 2001) reaches the leaves through the transpiration stream (Shen and Ma 2001) and moves symplastically, eventually reacting with pectins (Wehr et al. 2010) on the phloem cell wall. However, such similar mechanism was not yet evidenced for Al-accumulating species from the Cerrado due to a lack of semi-controlled studies with these plants growing on non-Al contaminant soils and Alrich soils.

In contrast to Andrade et al. (2011), who observed hematoxylin staining of the palisade leaf parenchyma with staining density among the chloroplasts of Q. grandiflora, our results show no hematoxylin or CAS (positive) reactions with this tissue in leaves of this species, which is also in accordance with Haridasan et al. (1986). This unusual observation made by
Andrade et al. (2011) for Al-accumulating plants is unique in the recent literature (Brunner and Sperisen 2013). Furthermore, we found no positive reaction of any dye with the internal contents of chloroplasts.

The Al-constitutive granules observed into cavities of the parenchyma in the midrib of the Alaccumulating plant, Q. parviflora (Fig. 4b, c), and of the non-accumulating species, S. camporum (Fig. 5d), suggest that Al can be evidenced in both groups of plants from the Cerrado, and this invalidates our hypothesis that $\mathrm{Al}$ can be observed only in Al-accumulating species. Although detectable with SEM/EDS in Q. parviflora (Fig. 4d), Al was hardly stained by CAS in the cavities (Fig. 4b). This occurs probably because CAS does not stain Al not bound to the cell wall, such as in 
Fig. 5 Anatomical analyses from cross-sections of leaf midribs of $S$. camporum performed under light microscopy (a and b) and SEM (c and d). a: non-stained; $\mathbf{b}$ : stained with chrome azurol S. c: general view of the collenchyma region, evidencing small granules; $\mathbf{d}$ : details from the same region of the collenchyma showing a granule in an amplified view; e: Al- and Si-specific energy-dispersive $\mathrm{x}$-ray spectra from a granule and from a collenchyma cell wall. Scale bars: $\mathbf{a}$ and $\mathbf{b}=200 \mu \mathrm{m} ; \mathbf{c}=15 \mu \mathrm{m}$; d $=45 \mu \mathrm{m}$
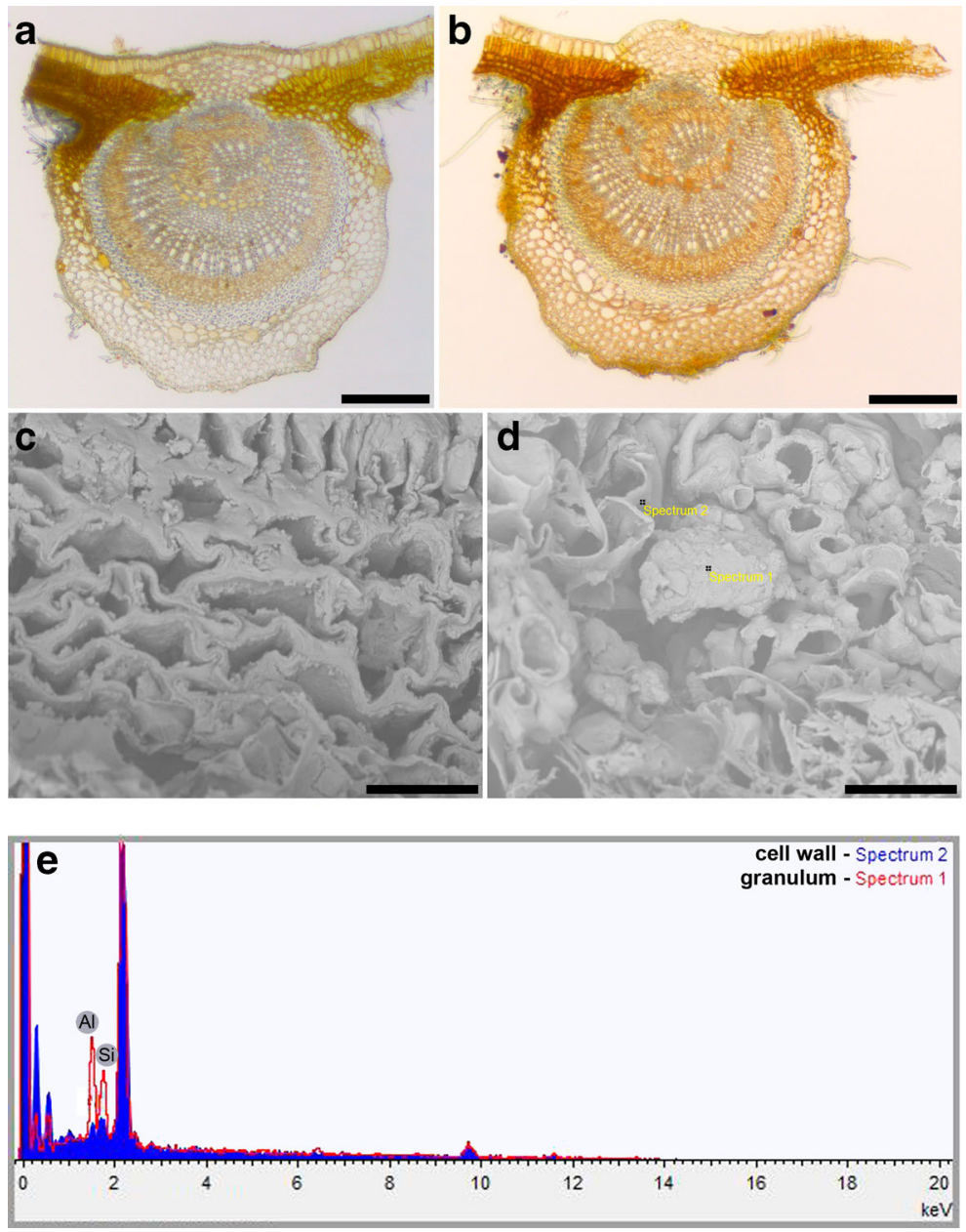

granules, and CAS positive reaction is dependent on pectin-Al complexes in order to stain in purple at the correct $\mathrm{pH}$ (Wehr et al. 2010). In the case of $S$. camporum, granules were not observed under light microscopy, and CAS did not stain the plant material (Fig. 5b), although Al was detected by SEM/EDS in granules (Fig. 5d, e). Nevertheless, S. camporum showed more than $1300 \mathrm{mg}$ Al per kg dry leaves (Table 2), and it could be reclassified as an Al accumulator. According to Chenery (1948), plant species showing at least $1000 \mathrm{mg} \mathrm{Al}$ per kg dry leaves or shoots can be considered Al accumulators.

These Al-constitutive granules observed in Q. parviflora and S. camporum may suggest a structural rather than functional role of $\mathrm{Al}$ in leaves of Cerrado plants. The Al concentration in mature leaves of M. albicans, M. rubiginosa, M. fallax and
Q. grandiflora increases by more than $320 \%$ in relation to their young leaves (Souza et al. 2015), suggesting that the granules we observed may be an effect of $\mathrm{Al}$ accumulation during leaf expansion, rather than existing structures in these species. On the other hand, we cannot tell whether plants of the same species not exposed to $\mathrm{Al}$ also show these cavities. Studies using these native species cultivated hydroponically in order to access their responses to $\mathrm{Al}$ are extremely rare.

Granules associated with $\mathrm{Al}$ and $\mathrm{Si}$, as evidenced by specific x-ray emission intensities in the Al-accumulating plants may also suggest that these plants attempt, somehow, to isolate the $\mathrm{Al}$ from metabolism. Not only granules associated with $\mathrm{Al}$ and $\mathrm{Si}$, as found in $Q$. parviflora (Fig. 4d) and S. camporum (Fig. 5e), but nongranular $\mathrm{Al}$ and $\mathrm{Si}$ association was also found in the phloem of $M$. rubiginosa (Fig. $3 \mathrm{e}, \mathrm{f}$ ). 
Fig. 6 Anatomical analyses from cross-sections of leaf midribs of S. ferrugineus performed under light microscopy (a and b) and SEM (c and d). a: non-stained; $\mathbf{b}$ : stained with chrome azurol S; c: general view of the central midrib; d: details from the same region of the central midrib showing calcium oxalate crystals - druses. e: Al- and Ca-specific energy-dispersive $\mathrm{x}$-ray spectra from calcium crystals and a cell wall in the cortical parenchyma. $\mathbf{d r}=$ druses. Scale bars: $\mathbf{a}=100 \mu \mathrm{m} ; \mathbf{b}=200 \mu \mathrm{m}$; $\mathbf{c}=165 \mu \mathrm{m} ; \mathbf{d}=50 \mu \mathrm{m}$
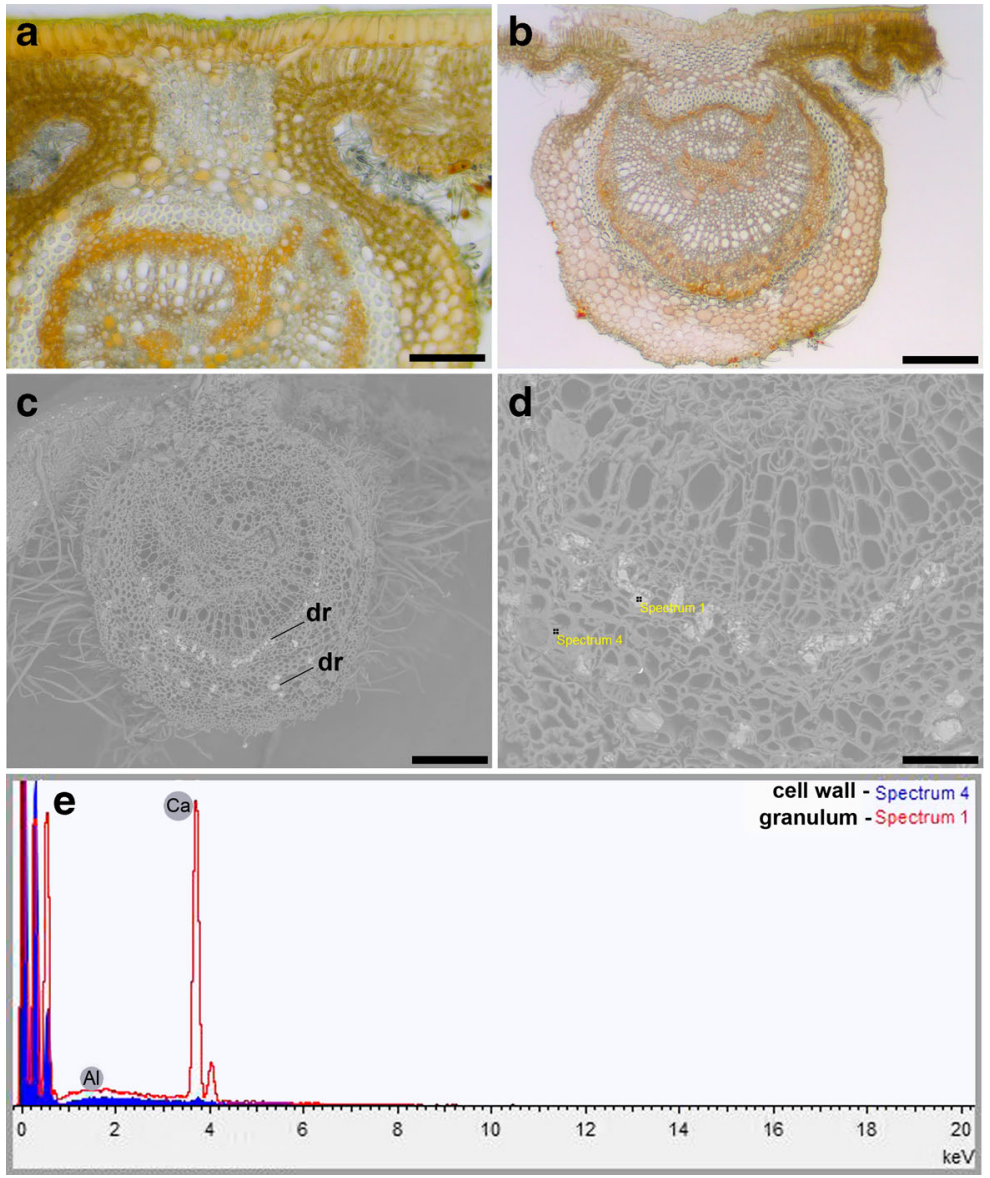

Precipitating $\mathrm{Al}$ with $\mathrm{Si}$ in the apoplast or symplast would constitute a detoxification mechanism since the aluminosilicate and solid Al-Si compounds are considered to be less toxic than monomeric $\mathrm{Al}\left(\mathrm{Al}^{3+}\right)$ (Britez et al. 2002), which can react with pectins on the cell wall (Wehr et al. 2010) and impair cell development. Si-associated grains, usually secreted into cavities, were already observed in Vochysiaceae and Styracaceae (Metcalf and Chalk 1989). But these authors did not risk assigning any physiological role to these grains. In the case of non-granular $\mathrm{Si}$ and $\mathrm{Al}$ association in the phloem (of $M$. rubiginosa), we cannot tell whether the binding to $\mathrm{Si}$ is involved in $\mathrm{Al}$ abundance in this tissue because we did not analytically measure $\mathrm{Si}$ in the plants and could not calculate $\mathrm{Si}$ Al ratios. Moreover, there is no information about $M$. rubiginosa or Melastomataceae being Si-accumulator, and this should also merit further studies. Silicon and Al seem to be associated in
Faramea marginata (Rubiaceae) (Britez et al. 2002), but no functional roles are described for these salts either.

One could still argue that the granules we observed filling the cavities in Q. parviflora (Figs. 4b, c) could be possible contamination or solidified artifact due to its fixation process or sectioning during the preparation of SEM. However, the Al and Si x-ray spectra emission from these granules were considerably prominent (Fig. 4d), not suggesting them as artifacts, contamination or methodological errors. Andrade et al. (2011) also showed these cavities in Q. grandiflora and Callisthene major (Vochysiaceae), although these authors did not explore the cavities' contents. These same cavities were also described for Q. grandiflora (unpublished data MSc. Dissertation, Renata Cristina Costa e Silva, University of Brasilia, UnB, Brazil). Our study is the first report suggesting that these cavities contain Al- and $\mathrm{Si}$-rich granules. Therefore, further investigation is necessary. 


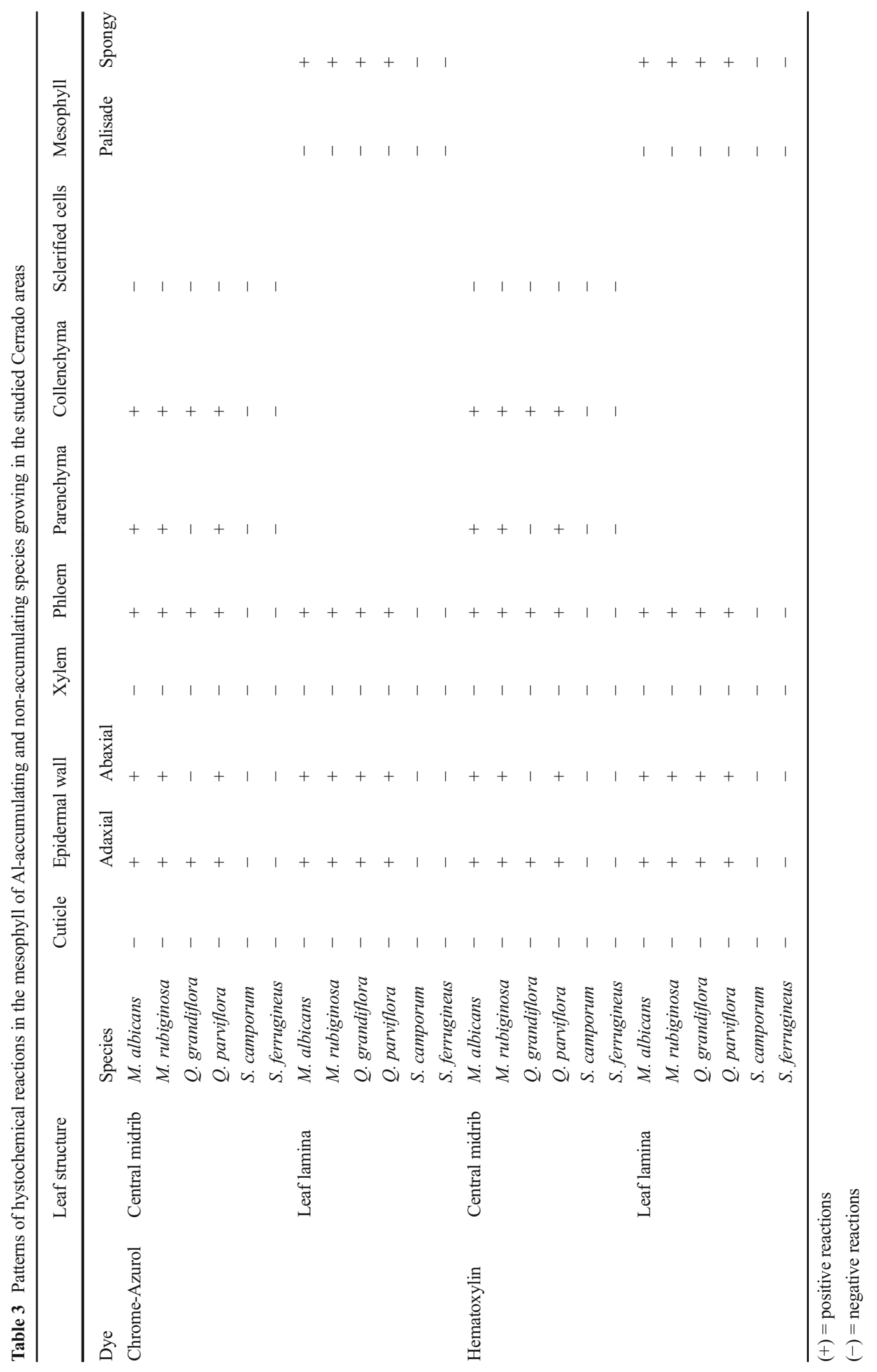


In angiosperms, crystals are formed by calcium oxalate and carbonate, but when $\mathrm{Ca}$ is low or not available in the soil as to form crystals, it may be replaced with other element (Metcalf and Chalk 1989), which might occur for Al-accumulating and non-accumulating plants. Notwithstanding, these mechanisms ( $\mathrm{Si}$ and $\mathrm{Ca}$ grains associated with Al) still do not explain the Al-dependence of some species in the Cerrado (Haridasan 2008).

In conclusion, we emphasize the high efficiency of CAS as an Al dye when compared to hematoxylin. In addition, our results reinforce that the primary cell wall is the main site for $\mathrm{Al}$ accumulation in these plants. We show that Al- and Si-constitutive granules are embedded on the cell wall of nonlignified leaf tissues of both Al-accumulating and non-accumulating species. Therefore, our results obtained from the few Al-accumulating species available in the Cerrado challenge the possibility that the Al might have a physiological function in these plants. Being found on the (primary) cell wall and as granules decreases a possible physiological role for $\mathrm{Al}$ in leaves of Cerrado woody plants. These findings also suggest that the $\mathrm{Al}$ is accumulated in these sites as a possible mechanism to detoxify $\mathrm{Al}$ in leaves of these plants.

Acknowledgments We acknowledge the Brazilian National Council for Scientific and Technological Development (CNPq) for the financial support (\#474169/2013-8 to G.H.), the MSc. fellowship to A.C.G. Bressan, and the research productivity fellowships to A. I. Coan (\#306498/2012-0) and G. Habermann (\#308902/2014-9). We thank Silvia R. Machado, Joecildo F. Rocha, and Tatiane M. Rodrigues for their comments on the early versions of the manuscript. This work was also supported by the São Paulo Research Foundation (Fapesp) [\#2012/01351-9 to G.H.].

\section{References}

Andrade LRM, Barros LMG, Echevarria GF, do Amaral LIV, Cotta MG, Rossatto DR, Haridasan M, Franco AC (2011) Al-Hyperaccumulator Vochysiaceae from the Brazilian Cerrado store aluminum in their chloroplasts without apparent damage. Env Exp Bot 70:37-42

Britez RM, Watanabe T, Jansen S, Reissmann CB, Osaki M (2002) The relationship between aluminium and silicon accumulation in leaves of Faramea marginata (rubiaceae). New Phytol 156:436-444

Brunner I, Sperisen C (2013) Aluminum exclusion and aluminum tolerance in woody plants. Front Plant Sci 4:1-12
Carr HP, Lombi E, Küpper H, McGrath SP, Wong MH (2003) Accumulation and distribution of aluminium and other elements in tea (Camellia sinensis) leaves. Agronomie 23:705710

Chenery EM (1948) Aluminium in the plant world. part I: general survey in dicotyledons. Kew Bull 1948:173-183

Dantas VL, Batalha MA (2011) Vegetation structure: fine scale relationships with soil in a cerrado site. Flora 206:341-346

González-Santana IH, Márquez-Guzman J, Cram-Heydrich S, Cruz-Ortega R (2012) Conostegia xalapensis (melastomataceae): an aluminum accumulator plant. Physiol Plant 144:134-145

Habermann G, Bressan ACG (2011) Root, shoot and leaf traits of the congeneric Styrax species may explain their distribution patterns in the cerrado Sensu lato areas in Brazil. Funct Plant Biol 38:209-218

Haridasan M (1982) Aluminium accumulation by some cerrado native species of Central Brazil. Plant Soil 65:265-273

Haridasan M (2008) Nutritional adaptations of native plants of the cerrado biome in acid soils. Braz J Plant Physiol 20:183-195

Haridasan M, Paviani TI, Schiavini I (1986) Localization of aluminium in the leaves of some aluminium-accumulating species. Plant Soil 94:435-437

Jansen S, Robbrecht E, Beeckman H, Smets E (2000) Aluminium accumulation in rubiaceae: An additional character for the delimitation of the subfamily rubioideae? IAWA J 21:197212

Jansen S, Watanabe T, Smets E (2002) Aluminium accumulation in leaves of 127 species in melastomataceae, with comments on the order mirtales. Ann Bot 90:53-64

Jansen S, Watanabe T, Dessein S, Smets E, Robbrecht E (2003) A comparative study of metal levels in leaves of some AlAccumulating Rubiaceae. Ann Bot 91:657-663

Johansen DA (1940) Plant microtechnique. McGraw-Hill Book Co, New York

Kennedy JA, Powell HKJ (1986) Colorimetric determination of aluminium (III) with chrome azurol S and the reactivity of hydrolysed Al species. Anal Chim Acta 184:329-333

Kopittke PM, Blamey FPC, Menzies NW (2008) Toxicities of soluble $\mathrm{Al}, \mathrm{Cu}$, and $\mathrm{La}$ include ruptures to rhizodermal and root cortical cells of cowpea. Plant Soil 303:217-227

Kukachka BF, Miller R (1980) A chemical spot-test for aluminum and its value in wood identification. IAWA Bull 3:104-109

Maejima E, Hiradate S, Jansen S, Osaki M, Watanabe T (2014) Comparative analysis of aluminum accumulation in leaves of three angiosperm species. Bot 92:327-331

Metcalf CR, Chalk L (1989) Anatomy of the dycotiledons: wood structure and conclusion of the general introduction. Oxford University Press, Oxford

Pakalns P (1965) Spectrophotometric determination of aluminium with chrome azurol S. Anal Chim Acta 32:57-63

Robson AD (1989) Soil acidity and plant growth. Academic Press, Sydney

Ryan PR, Tyerman SD, Sasaki T, Furuichi T, Yamamoto Y, Zhang WH, Delhaize E (2011) The identification of aluminiumresistance genes provides opportunities for enhancing crop production on acid soils. J Exp Bot 62:9-20

Sarruge JR, Haag HP (1974) Análises Químicas em plantas. Escola Superior de Agricultura Luiz de Queiróz, Piracicaba[In Portuguese] 
Shen R, Ma JF (2001) Distribution and mobility of aluminium in an Al-accumulating plant, Fagopyrum esculentum moench. J Exp Bot 52:1683-1687

Souza MC, Bueno PCP, Morellato LPC, Habermann G (2015) Ecological strategies of Al-accumulating and nonaccumulating functional groups from the cerrado sensu stricto. Ann Acad Bras Ciên 87:813-823 doi:10.1590/00013765201520140222

Tolrà R, Vogel-Mikus K, Hajiboland R, Kump P, Pongrac P, Kaulich B, Gianoncelli A, Babin V, Barceló J, Regvar M, Poschenrieder C (2011) Localization of aluminium in tea (Camellia sinensis) leaves using low energy X-ray fluorescence spectro-microscopy. J Plant Res 124:165-172

van Raij B, Andrade JC, Cantarella H, Quaggio JA (2001) Análise química para avaliação da fertilidade de solos tropicais. Instituto Agronômico de Campinas (IAC), Campinas
vonUexküll HR, Mutert E (1995) Global extent, development and economic impact of acid soils. In: Date RA et al. (eds) Plant soil interactions at low $\mathrm{pH}$. Kluwer Academic Publ, Dordrecht, pp. 5-19

Watanabe T, Osaki M (2001) Influence of aluminum and phosphorus on growth and xylem sap composition in Melastoma malabathricum L. Plant Soil 237:63-70

Wehr JB, Blamey FPC, Hanna JV, Kopittke PM, Kerven GL, Menzies NW (2010) Hydrolysis and speciation of Al bound to pectin and plant cell wall material and its reaction with the dye chrome azurol S. J Agric Food Chem 58:5553-5560

Wigley BJ, Coetsee C, Hartshorn AS, Bond WJ (2013) What do ecologists miss by not digging deep enough? insights and methodological guidelines for assessing soil fertility status in ecological studies. Acta Oecol 51:17-27

Yang ZB, Rao IM, Horst WJ (2013) Interaction of aluminium and drought stress on root growth and crop yield on acid soils. Plant Soil 372:3-25 